\title{
Studies on the aetiology of byssinosis
}

\author{
GEOFFREY TAYLOR, A. A. E. MASSOUD, and F. LUCAS \\ University of Manchester and Shirley Institute, Manchester
}

\begin{abstract}
Taylor, G., Massoud, A. A. E., and Lucas, F. (1971). Brit. J. industr. Med., 28, 143-151. Studies on the aetiology of byssinosis. A condensed polyphenol based on leucocyanidin has been extracted from the cotton plant. The reaction between this material and human serum has been demonstrated using both a precipitin and a passive agglutination technique. Sera from 196 cardroom workers not suffering from byssinosis, 177 byssinotic cardroom workers, and 203 controls were tested for reactivity with the condensed polyphenol using the passive agglutination technique. Significant differences in mean titres were obtained between cardroom workers and controls and between byssinotic and non-byssinotic cardroom workers. It was shown that while the mean titre in non-byssinotic cardroom workers remains relatively constant with respect to duration of employment, the titre in those cardroom workers suffering from byssinosis shows a progressive rise with duration of cardroom exposure.

Inhalation of solutions of the condensed polyphenol by normal control subjects and by non-byssinotic cardroom workers produced neither symptoms nor changes in $\mathrm{FEV}_{\mathbf{1 . 0}}$ or FVC. On the other hand, inhalation of the material by byssinotic cardroom workers induced symptoms identical with those experienced on exposure in the cardroom on Mondays. Because of the subjective nature of byssinosis, this inhalational study was repeated as a double-blind trial which completely confirmed the above observations.
\end{abstract}

The object of this investigation was to follow up the observations of Massoud and Taylor (1964) that cardroom workers suffering from byssinosis have higher titres of antibody directed against an antigen present in the cotton plant than non-byssinotic cardroom workers who in turn have higher titres than the general population.

Massoud and Taylor presented an hypothesis which attempts to explain these findings, and which suggests that the symptoms of byssinosis are produced by an intrapulmonary antigen-antibody reaction involving this antigen-antibody system. In order to explain the findings of antibody in normal non-textile workers it is assumed that the antigen is one which is found in the general environment, but that because cotton workers have higher titres than the general population the antigenic stimulation gained from working in the cotton industry is much greater than that obtained in other environments. It is suggested that during the early years of work in those parts of the cotton mill in which cottonantigen-containing dust is found, the worker builds up his level of antibody from that found in the 'normal' group to that found in the group of cardroom workers. The amount of antibody produced will depend on the worker's own inherent ability to produce antibody. The better antibody producers will have the highest antibody levels, as found in byssinotic cardroom workers. Following exposure to dust on Monday morning it is suggested that an antigen-antibody reaction takes place in the lungs. The magnitude of the reaction will be largely determined by the amount of available antibody. The symptoms of byssinosis are produced directly by the action of antigen-antibody complex on the capillaries in the peripheral part of the lung. In normal subjects or in cardroom workers with low antibody titres, the amount of antigen-antibody complex produced is 
small, and the resulting lung changes are insignificant and unnoticed. In the byssinotic subjects exposure to cotton antigen results in a large amount of antigenantibody complex, and symptoms appear. As a result of the reaction, the amount of circulating antibody decreases, and on further exposure to dust on Tuesday there is not sufficient complex formed to produce symptoms. In advanced cases of byssinosis with symptoms on Tuesdays and sometimes on other days of the week, it may be postulated that absorption of antibody on Monday leaves sufficient still available to produce a reaction on exposure to cotton dust later in the week. Over the weekend, during which the cardroom worker is not exposed to the cotton antigen, the antibody is no longer removed daily from the circulation and the antibody titre rises. The amount of antibody is again high enough on Monday to produce further symptoms. The most severe attacks of byssinotic symptoms are after the annual holidays, when a longer period away from the antigen may have resulted in much higher antibody levels than are found after the two-day weekend absence from work.

The investigation reported attempts to substantiate this general hypothesis.

\section{Isolation of the cotton plant antigen}

Bracts from dried cotton bolls were ground to a powder in a hammer mill. The powder was extracted in a Soxhlet apparatus first with light petroleum (B.P. $60^{\circ}$ to $80^{\circ}$ ) and then with ethanol, and allowed to dry in the air.

One hundred grammes of the extracted bracts were stirred with water $(11$.$) for 3$ hours and the liquor was removed by centrifugation. The bracts were again stirred with water $(500 \mathrm{ml})$ for $1 \frac{1}{2}$ hours and the mixture was centrifuged. The combined supernatants were filtered and 0.1 M lead acetate solution $(500 \mathrm{ml})$ was added slowly with vigorous stirring. The precipitate was centrifuged off and washed twice by dispersion in water $(500 \mathrm{ml})$ in a Waring blender and centrifugation. The precipitate was again dispersed in water $(250 \mathrm{ml})$ and $1.8 \mathrm{M}$ sulphuric acid $(13.5 \mathrm{ml})$ was added with vigorous stirring. The precipitate was centrifuged off and dispersed in more water $(100 \mathrm{ml})$ to which $1.8 \mathrm{M}$ sulphuric acid $(2 \mathrm{ml})$ was added. After centrifugation, lead was removed from the combined supernatants, which were slightly cloudy, by the addition of ethylenediaminetetra-acetic acid di-sodium salt $(1.7 \mathrm{~g}$ in $35 \mathrm{ml})$ and dialysis for 24 hours in a Visking sac against running deionized water. The solution was then evaporated to about $150 \mathrm{ml}$ on a rotary evaporator with a bath temperature not exceeding $40^{\circ} \mathrm{C}$. Absolute ethanol ( $3 \mathrm{vol})$ was added to the solution with vigorous stirring and the precipitate formed was removed by centrifugation. The supernatant liquor was reduced to a small volume (about $50 \mathrm{ml}$ ) by rotary evaporation at $40^{\circ} \mathrm{C}$ and the solution was freeze-dried, to yield the antigen as a fawn powder.

\section{Properties of the cotton plant antigen}

The antigen is a light fawn coloured powder. Freshly prepared it is soluble up to approximately $15 \mathrm{mg} / \mathrm{ml}$ in physiological saline, giving a straw-coloured solution with a pH of about 3.0. Both as a solid and in solution it readily oxidizes to an insoluble product; thus solutions must be freshly prepared, and the solid antigen should be stored in sealed containers. Chemical examination of the antigen, which will be published in detail elsewhere, shows it to be a complex condensed polyphenol based on leucocyanidin $\left(5,7,3^{\prime}, 4^{\prime}\right.$-tetrahydroxyflavan-3,4-diol) with smaller amounts of leucodelphinidin $\left(5,7,3^{\prime}, 4^{\prime}, 5^{\prime}\right.$-pentahydroxyflavan-3,4-diol). The molecular weight of the antigen as prepared above is in the range 10000 to 15000 . The antigen belongs to the group of compounds known as condensed tannins which are present in many plants.

As it was proposed to carry out inhalation tests of antigen on human volunteers it was necessary to determine the toxicity of the antigen. Conventional $\mathrm{LD}_{50}$ determinations were made in mice, administering the antigen dissolved in saline by intraperitoneal injection. The $\mathbf{L D}_{50}$ for male mice was $386 \mathrm{mg} / \mathrm{kg}$ body weight, and that for female mice was $281 \mathrm{mg} / \mathrm{kg}$. In addition, the toxicity of the antigen was also investigated by intratracheal injection in rats. Doses of $10 \mathrm{mg}$ antigen dissolved in saline were given by intratracheal injection into 10 rats. Control rats received saline only. Two rats in the test group died shortly after the injections. Death was due to massive pulmonary collapse and was considered to be caused by faulty technique. The other rats remained well, and at necropsy seven days later showed no abnormalities.

Agents with pharmacological activity on smooth muscle have been repeatedly isolated from cotton dust. These have included histamine, histamine liberator substances, 5-hydroxytryptamine, and smooth muscle contractor substances of unknown nature. It was felt necessary to test the antigen preparations for pharmacological activity.

Guinea-pig ileum was incubated in Tyrode solution in an organ bath with 125,250 , and $500 \mu \mathrm{g} / \mathrm{ml}$ antigen. No histamine-like activity was detected. With $500 \mu \mathrm{g} / \mathrm{ml}$ a slow, weak, delayed contraction occurred rather like that produced by SRS-A. This could not be blocked by compound FPL 1195, which specifically blocks SRS-A. The contraction was considered to be of a non-specific nature, possibly related to the relatively low $\mathrm{pH}$ of the antigen solutions.

The activity of the antigen on smooth muscle was further tested on human bronchial chains, again using 125,250 , and $500 \mu \mathrm{g} / \mathrm{ml}$. No contractions whatsoever occurred. This further bears out the suggestion that the weak reactions against guinea-pig ileum were non-specific.

The ability to release histamine from tissue was tested on human chopped lung. This was incubated 
with antigen in concentrations of 125,250 , and $500 \mu \mathrm{g} / \mathrm{ml}$, and the supernatant was tested for histamine and SRS-A content. Controls of chopped lung without antigen were similarly tested. No significant difference was found between test and control tubes.

These experiments indicate that the cotton antigen prepared as already described is free of smooth muscle spasmogenic activity.

The cotton plant antigen has been shown to belong to the group of substances known as condensed tannins, and as these substances have known nonspecific protein-precipitating properties it is necessary to comment on the reaction between the antigen and specimens of serum. In high concentration both the free acid and to a less extent the sodium salt of the antigen will non-specifically precipitate a variety of proteins including human serum proteins. This presents a considerable problem in the interpretation of the mechanisms involved in the reaction. Several points, however, suggest that in addition to the nonspecific protein precipitation at high concentrations an immunological specificity also occurs under other conditions. These observations are:

(a) The antigen reacts both by precipitation and by passive agglutination with purified human IgG.

(b) Human serum in high dilution causes the agglutination of particles coated with very small quantities of antigen.

(c) This agglutination varies from serum to serum by as great a factor as 10000 -fold, suggesting that it is reacting with a serum component which is very variable in concentration from individual to individual. This is unlike the responses expected if the reaction were purely non-specific.

(d) Red cells coated with low concentrations of antigen will lyse in the presence of fresh unheated human serum but not with serum heated at $56^{\circ} \mathrm{C}$ for 30 minutes. That is, during the reaction between human serum and antigen at the surface of a red cell complement is bound. The amount of lysis could be increased by adding heated serum from a cardroom worker to the system.

Further work is being done to rule out the possibility that these are not specific immune reactions. But in this report the human serum component which reacts with cotton plant 'antigen' is referred to as antibody.

\section{Serological survey}

\section{Subjects}

The cotton workers included in the survey were all volunteers and were contacted by arrangement with the management of the mill, the industrial medical officer of the mill, and the union concerned. The co-operation achieved was very gratifying.

The mills investigated were: The Eagle, The Leesbrook, The Banktop, The Fox, The Maple, The Newby, The
Royd, The Ash, The Era, The Delta, The Lowfield, and The Lilac. All were situated in the Oldham/Rochdale area. All the mills were processing medium- and coarsegrade cotton.

The cotton workers were asked to fill in a questionnaire which asked for the following information: name; address; age; employment (both present and past); duration of employment; smoking habits; applications for industrial compensation; illnesses subdivided into bronchitis, asthma, hay fever, heart trouble, shortage of breath, and chest symptoms on Mondays. This questionnaire was checked at interview and at the same time a decision was made as to the presence or absence of byssinosis and, if present, its grade (Schilling, Hughes, Dingwall-Fordyce, and Gilson, 1955).

The normal controls were university and hospital staff and hospital patients who were not cotton workers. None of them suffered from byssinosis. The numbers of subjects investigated are shown in Table 1.

TABLE 1

Number of Subjects in EAch Group

\begin{tabular}{|c|c|c|c|}
\hline & Male & Female & Total \\
\hline $\begin{array}{ccc}\text { Normal controls } & \text { (no } \\
\text { exposure) } & . & \ldots\end{array}$ & 102 & 101 & 203 \\
\hline $\begin{aligned} \text { Cardroom workers } & \\
\text { Non-byssinotic } & \ldots \\
\text { Byssinosis grade } \frac{1}{2} & \ldots \\
\text { grade I } & \ldots \\
\text { grade II } & \ldots\end{aligned}$ & $\begin{array}{l}73 \\
18 \\
31 \\
27\end{array}$ & $\begin{array}{r}123 \\
25 \\
45 \\
31\end{array}$ & $\left.\begin{array}{l}196 \\
43 \\
76 \\
58\end{array}\right\} 177$ \\
\hline
\end{tabular}

\section{Serum samples}

Venous blood, $10 \mathrm{ml}$, was allowed to clot at $37^{\circ} \mathrm{C}$ for 1 hour and was then left at $4^{\circ} \mathrm{C}$ overnight. Serum was separated and stored at $-25^{\circ} \mathrm{C}$ until required for titration. Blood samples from the normal group were taken at random times, but all samples from the cotton workers were taken before the start of work on a Monday morning.

\section{Titration of sera}

The antigen used was the several batches of 'pure' sodium salt of the antigen prepared at the Shirley Institute. A solution of $10 \mathrm{mg} / \mathrm{ml}$ was made in $0.85 \%$ sodium chloride and was then centrifuged at 15000 r.p.m. for 60 minutes at $4^{\circ} \mathrm{C}$ in a MSE high-speed ' $18^{\prime}$ ' refrigerated centrifuge. This removed very fine insoluble material which seemed to develop after storage of dry preparations of the antigen. Barium sulphate (Analar) was separated by water flotation into three sizes of particles. The most coarse and the most fine were discarded. The same batch of barium sulphate was used throughout. For sensitization of the particles a $3 \% \mathrm{w} / \mathrm{v}$ suspension of barium sulphate in isotonic saline was mixed with an equal volume of antigen $(10 \mathrm{mg} / \mathrm{ml})$. The mixture was shaken for 10 minutes at room temperature and then the barium sulphate was washed three times in large volumes of saline. The 'sensitized' barium sulphate was resuspended 
to the original volume of the antigen in $0.5 \%$ bovine serum albumin solution in $0.85 \%$ sodium chloride. Freshly sensitized barium sulphate was made for each batch of tests.

Dilutions of $10^{-3}, 5 \times 10^{-3}, 10^{-4}, 5 \times 10^{-4}, 10^{-5}$, $5 \times 10^{-5}, 10^{-6}, 5 \times 10^{-6}$ were tested. The serological testing was carried out without knowledge of the clinical findings.

\section{Results}

The distribution of titres in the normal controls and cardroom groups is shown in Table 2. It is clearly seen that there is a different distribution of titres in the two groups, and that the cardroom workers as a group have higher titres than the controls. The geometric mean titre in the control group was 52090 . The standard error of the mean (S.E.M.) was calculated and the $95 \%$ confidence limits of the mean ( \pm 2 S.E.M.) in the control group were 45310 to 59850 . In comparison the mean of the cardroom worker group was 175400 with $95 \%$ confidence limits of 157000 to 195900 .

TABLE 2

Titres in Normal Controls and in Cardroom WORKERS

\begin{tabular}{|c|c|c|c|c|c|c|}
\hline & & & \multicolumn{2}{|c|}{ Control group } & \multicolumn{2}{|c|}{$\begin{array}{c}\text { Cardroom worker } \\
\text { group }\end{array}$} \\
\hline \multicolumn{3}{|c|}{ Titre } & No. & $\%$ & No. & $\%$ \\
\hline $\begin{array}{l}10^{4} \\
5 \times 10^{4} \\
10^{5} \\
5 \times 10^{5} \\
10^{6} \\
5 \times 10^{6}\end{array}$ & $\begin{array}{l}\ldots \\
\ldots \\
\ldots \\
\ldots \\
\ldots\end{array}$ & $\begin{array}{l}\ldots \\
\ldots \\
\ldots \\
\ldots \\
\ldots \\
\cdots\end{array}$ & $\begin{array}{r}29 \\
76 \\
81 \\
15 \\
2 \\
0\end{array}$ & $\begin{array}{r}14 \\
37 \\
40 \\
7 \\
1 \\
0\end{array}$ & $\begin{array}{r}8 \\
34 \\
153 \\
125 \\
52 \\
1\end{array}$ & $\begin{array}{r}2 \\
9 \\
41 \\
34 \\
14 \\
0\end{array}$ \\
\hline Total & .. & . & 203 & & 373 & \\
\hline
\end{tabular}

The results in the cardroom worker group were examined to see if there was any tendency for the titre to rise with increasing length of exposure. The results of this analysis are shown in Table 3 . It will be seen that there is some tendency for the titres to rise with duration of work in the cardroom. This is particularly evident if those individuals with titres above and below $10^{6}$ are compared.

In order to determine that this observation is not related to age rather than to length of exposure in the cardroom the distribution of titres with age was studied in the control group. Table 4 shows the results.

There appears to be no tendency for the titre to rise with age and hence it is likely that the observed change in distribution of titres with length of time
TABLE 3

All Cardroom Workers:

YeArs OF EXPOSURE VERSUS ANTIBODY TITRE (Percentages)

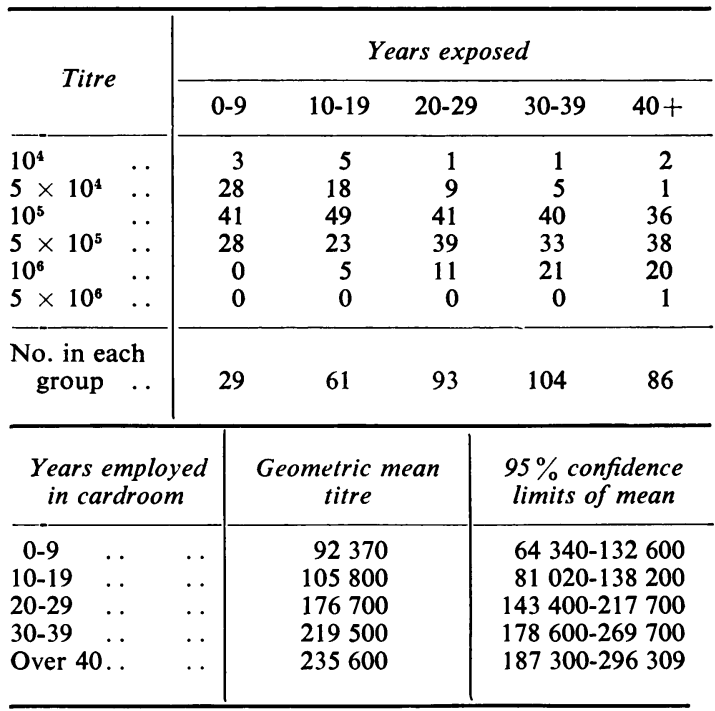

working in the cardroom is a direct result of this occupation.

The cardroom worker group was divided into those without symptoms of byssinosis and those with symptoms of grades $\frac{1}{2}$, I, and II. The byssinotic groups were combined together because if separated

TABLE 4

Antibody Titres in Normal Controls with Age (Percentages)

\begin{tabular}{|c|c|c|c|c|c|c|}
\hline \multirow{2}{*}{\multicolumn{3}{|c|}{ Titre }} & \multicolumn{4}{|c|}{ Age $(y r)$} \\
\hline & & & $15-19$ & $30-44$ & $45-59$ & $60+$ \\
\hline $\begin{array}{l}10^{4} \\
5 \times 10^{4} \\
10^{5} \\
5 \times 10^{5} \\
10^{6} \ldots \\
5 \times 10^{6}\end{array}$ & $\begin{array}{l}\ldots \\
\ldots \\
\ldots \\
\ldots \\
\ldots\end{array}$ & $\begin{array}{l}\cdots \\
\ldots \\
\cdots \\
\cdots \\
\cdots \\
\ldots\end{array}$ & $\begin{array}{r}11 \\
26 \\
52 \\
11 \\
0 \\
0\end{array}$ & $\begin{array}{r}28 \\
50 \\
18 \\
2 \\
2 \\
0\end{array}$ & $\begin{array}{r}6 \\
35 \\
49 \\
10 \\
0 \\
0\end{array}$ & $\begin{array}{r}10 \\
35 \\
45 \\
8 \\
2 \\
0\end{array}$ \\
\hline \multicolumn{2}{|c|}{ No. in group } & $\ldots$ & 35 & 56 & 63 & 49 \\
\hline \multicolumn{2}{|c|}{$\begin{array}{c}\text { Age group } \\
(y r)\end{array}$} & \multicolumn{3}{|c|}{$\begin{array}{c}\text { Geometric mean } \\
\text { titre }\end{array}$} & \multicolumn{2}{|c|}{$\begin{array}{l}95 \% \text { confidence } \\
\text { limits of mean }\end{array}$} \\
\hline $\begin{array}{l}15-29 \\
30-44 \\
45-59 \\
\text { Over } 60 .\end{array}$ & & & $\begin{array}{ll}65 & 210 \\
31 & 030 \\
64 & 050 \\
61 & 050\end{array}$ & & $\begin{array}{ll}46 & 980 \\
23 & 940 \\
51 & 890 \\
46 & 930\end{array}$ & $\begin{array}{l}510 \\
210 \\
150 \\
410\end{array}$ \\
\hline
\end{tabular}


the groups were rather small for statistical analysis. The results are presented in Table 5 . The mean titre of the non-byssinotic cardroom workers was 125000 , with $95 \%$ confidence limits of 114100 to 137000 , while the mean titre of the byssinotic group was 255200 with $95 \%$ confidence limits of 218300 to 298300 . This is considered to be a highly significant difference between the two groups.

It has been demonstrated that there is a gradual rise in the mean antibody titre with length of employment in the cardroom. This was investigated further by subdividing both byssinotic and nonbyssinotic subjects by length of service in the cardroom and comparing the mean titres. The results are shown in Table 6 and graphically in the Figure. It will be seen that whereas the mean titre remains almost constant with respect to length of service in non-byssinotic subjects, in those who develop byssinosis the mean titre observed becomes progressively higher as the iength of employment in the cardroom increases.

There are two possible explanations for this finding. Either those who develop byssinosis receive a greater antigenic stimulus than those who do not, or byssinotics have greater antibody-forming poten-

TABLE 5

Distribution of Titres in Byssinotic and NonBYSSINOTIC CARDROOM WORKERS

\begin{tabular}{|c|c|c|c|c|c|c|}
\hline \multirow{2}{*}{\multicolumn{3}{|c|}{ Titre }} & \multicolumn{2}{|c|}{ Non-byssinotic } & \multicolumn{2}{|c|}{ Byssinotic } \\
\hline & & & No. & $\%$ & No. & $\%$ \\
\hline \multirow[t]{2}{*}{$\begin{array}{l}10^{4} \\
5 \times 10^{4} \\
10^{5} \\
5 \times 10^{5} \\
10^{6} \\
5 \times 10^{6}\end{array}$} & $\begin{array}{l}\ldots \\
\ldots \\
\ldots \\
\ldots \\
\cdots \\
\ldots\end{array}$ & $\begin{array}{l}. \\
\ldots \\
\ldots \\
\ldots \\
\ldots \\
\ldots\end{array}$ & $\begin{array}{r}6 \\
27 \\
96 \\
57 \\
10 \\
0\end{array}$ & $\begin{array}{r}3 \\
14 \\
49 \\
29 \\
5 \\
0\end{array}$ & $\begin{array}{r}2 \\
7 \\
57 \\
68 \\
42 \\
1\end{array}$ & $\begin{array}{r}1 \\
4 \\
32 \\
38 \\
24 \\
1\end{array}$ \\
\hline & & & 196 & & 177 & \\
\hline
\end{tabular}

tial than non-byssinotics. As all the workers at risk in this series are employed in the cardroom, and byssinosis is known to occur in some members of each occupational subgroup working within the cardroom, variation in antigenic stimulation appears to be an unlikely explanation for the observed differences in antibody response. Further, as we are considering a very slowly developing disease process, variations in antigenic stimulation which might occur on some days should be cancelled out over a period of months and years.

It is well recognized that in any biological system there will be variation about the mean with respect to any parameter. It was suggested by Massoud and Taylor (1964) that those who develop byssinosis on working for a period of time in the cardroom are those individuals who have greater inherent antibodyforming potential. This suggestion is in keeping with the observed results.

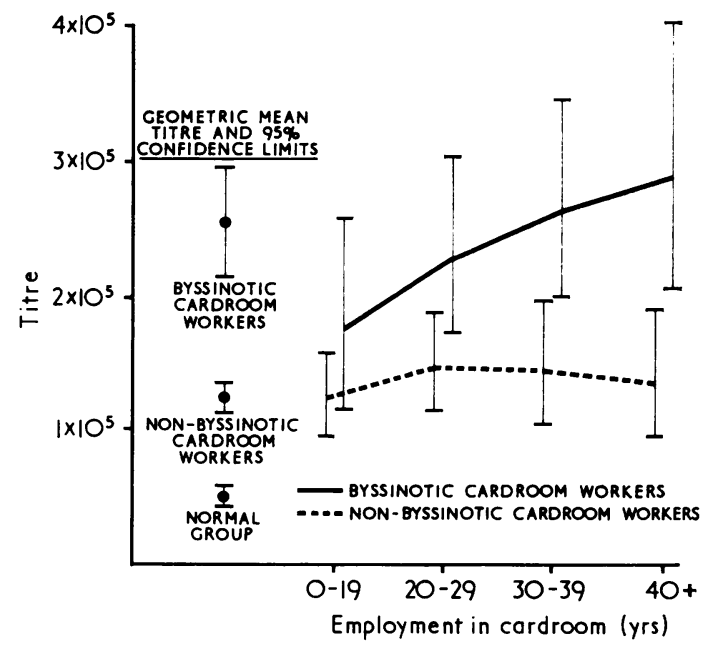

FIGURE. Difference in titre in byssinotic and in nonbyssinotic cardroom workers with respect to duration of employment.

TABLE 6

Change in Titre with Length of Employment IN BYSSINOTIC AND NON-BYSSINOTIC CARDROOM WORKERS

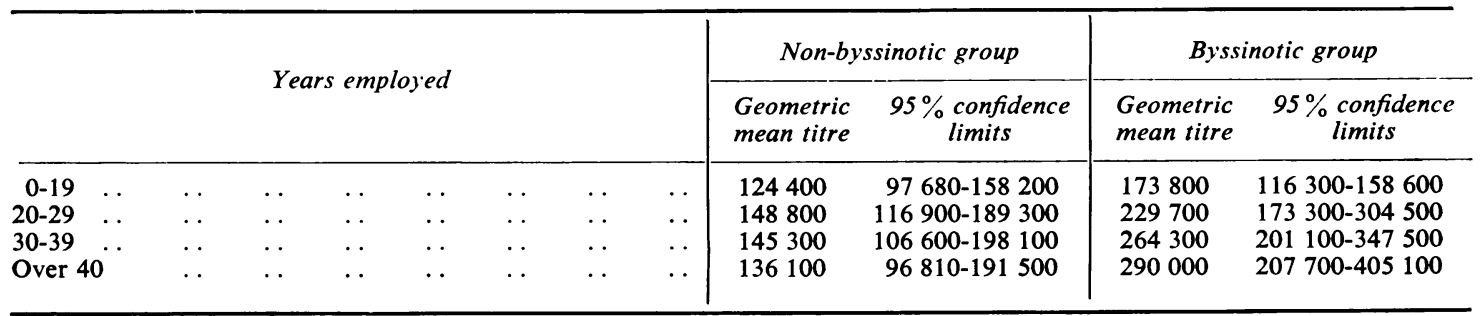




\section{Investigation of changes of titre in cotton cardroom} workers

The hypothesis proposed by Massoud and Taylor (1964) suggested that the non-occurrence of symptoms on Tuesdays and on other days of the week was due to absorption of antibody by inhalation of antigen. The titre of antibody would therefore be expected to be lower on weekdays other than Monday. It was suggested that the antibody titre would rise during periods when antigen inhalation was not taking place, that is, at weekends and during holidays.

\section{Subjects and serum samples}

Volunteer cardroom workers from the mills already listed provided the three samples of venous blood. The first was taken on the Monday morning before work started in the week preceding the annual holiday, the second on Friday afternoon of the same week, and the third on Monday morning before work on return from two weeks' holiday. A total of 107 complete sets of samples were collected. Incomplete sets were discarded. Of the 107 subjects 48 had symptoms of byssinosis and 59 were non-byssinotics.

Titration of sera

Sera were titrated in the same manner as described above but a second series of dilutions around the endpoint was tested in each case.

\section{Results}

Changes in titre during the working week The direction in which the titre changed from Monday to Friday was calculated in each case. The results, divided into byssinotics and non-byssinotics, are shown in Table 7. There is a tendency for the titre to fall from Monday to Friday but the results are by no means clear cut. There appears to be no significant difference between the behaviour of those with and those without byssinosis.

Changes in titre during two weeks' holiday The direction in which the titre changed from Friday afternoon before the annual holiday to Monday before work on the Monday after the holiday was calculated in each case. The results, divided into

TABLE 7

Change in Titre from Monday to Friday

\begin{tabular}{|c|c|c|c|c|c|c|}
\hline \multirow{2}{*}{\multicolumn{3}{|c|}{ Titre }} & \multicolumn{2}{|c|}{ Byssinotics } & \multicolumn{2}{|c|}{ Non-byssinotics } \\
\hline & & & No. & $\%$ & No. & $\%$ \\
\hline $\begin{array}{l}\text { Increase } \\
\text { No change } \\
\text { Decrease }\end{array}$ & $\begin{array}{l}\ldots \\
\cdots \\
\cdots\end{array}$ & $\begin{array}{l}\cdots \\
\cdots \\
\cdots\end{array}$ & $\begin{array}{r}9 \\
16 \\
23\end{array}$ & $\begin{array}{l}19 \\
33 \\
48\end{array}$ & $\begin{array}{r}9 \\
27 \\
23\end{array}$ & $\begin{array}{l}15 \\
46 \\
39\end{array}$ \\
\hline
\end{tabular}

byssinotics and non-byssinotics, are shown in Table 8.

On withdrawal from the five days per week exposure to antigen there was a clear tendency for the titre to rise. This substantiates the original hypothesis that the titre during work is held to a lower level by some antibody-absorption mechanism. There appears to be no difference in behaviour between byssinotic and non-byssinotic subjects.

\section{TABLE 8}

Change in Titre during Two Weeks' Holiday

\begin{tabular}{|c|c|c|c|c|c|c|}
\hline \multirow{2}{*}{\multicolumn{3}{|c|}{ Titre }} & \multicolumn{2}{|c|}{ Byssinotic } & \multicolumn{2}{|c|}{ Non-byssinotic } \\
\hline & & & No. & $\%$ & No. & $\%$ \\
\hline $\begin{array}{l}\text { Increase } \\
\text { No change } \\
\text { Decrease }\end{array}$ & $\begin{array}{l}\cdots \\
\cdots \\
\ldots\end{array}$ & $\begin{array}{l}\cdots \\
\ldots \\
\ldots\end{array}$ & $\begin{array}{r}34 \\
13 \\
1\end{array}$ & $\begin{array}{r}71 \\
27 \\
2\end{array}$ & $\begin{array}{r}50 \\
7 \\
2\end{array}$ & $\begin{array}{r}85 \\
12 \\
3\end{array}$ \\
\hline
\end{tabular}

\section{Inhalational studies in man}

Administration of antigen for bronchial challenge was by aerosol produced by a Wright nebulizer. The antigen was dissolved in saline in various concentrations. A standard rate of air flow of $6 \mathrm{l} / \mathrm{min}$ was produced by a cylinder of compressed air which was passed through the solution of antigen in the nebulizer. The aerosol was inhaled through a conventional anaesthetic mask fitting over the nose and mouth of the subject. The dose administered could be varied either by altering the concentration of antigen or by varying the time of inhalation. It is not possible to determine the actual dose of antigen retained by the subject as inevitably some antigen is lost in the mouth and in the nasal passages of the individual, and considerable antigen is passed out in expired air.

The first doses of antigen were taken by the investigators, followed by volunteers from among the laboratory staff. Simple respiratory function tests $\left(\mathrm{FVC}\right.$ and $\mathrm{FEV}_{\mathbf{1}_{0} \cdot \mathrm{0}}$ ) were carried out before and at intervals after the antigen dosage. Volunteers were questioned about any sensations or symptoms produced.

No changes in FVC or $\mathrm{FEV}_{1.0}$ were detected, and no symptoms were induced by antigen challenge in normal controls up to the highest dose tested, which was $500 \mu \mathrm{g} / \mathrm{ml}$ for 15 minutes. This result does not, however, indicate that such a dose is necessarily safe in a sufferer from byssinosis. The dose-response was, therefore, investigated in byssinotics, and as controls non-byssinotic cardroom workers were used.

Twenty-nine byssinotic cardroom workers, all with either Schilling grades I or II byssinosis but without symptoms suggestive of chronic bronchitis, were used. A further 29 non-byssinotic cardroom workers, all of whom had worked in the cardroom for at least 10 years, acted as controls.

Individuals were challenged on Monday morning after a two-day break from work. Varying concentrations of antigen for different lengths of time were used. The 
subjects were observed for the whole of the day, during which time they did not return to the cotton mill. Respiratory function tests (FVC and $\mathrm{FEV}_{1 \cdot 0}$ ) were carried out before and at intervals after challenge. They were seen again later in the same week and further questioned about any symptoms which might have occurred. Each individual was challenged on only one occasion.

\section{Results}

No significant change in FVC or $\mathrm{FEV}_{1.0}$ occurred after antigen challenge. Some individuals reported symptoms which they described as identical with those they usually experienced on working Mondays. The symptoms occurred with a time lag of from 3 to 6 hours and consisted of a sensation of chest tightness and some breathlessness. At this time respiratory function tests showed no changes as compared with pre-challenge values. The results of challenge in the 58 subjects are shown in Table 9.

\section{TABLE 9}

Bronchial Challenge with Cotton Plant ANTIGEN

\begin{tabular}{|c|c|c|c|}
\hline \multicolumn{2}{|c|}{ Antigen dosage } & \multicolumn{2}{|c|}{ 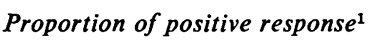 } \\
\hline $\begin{array}{l}\text { Concentration } \\
\quad(\mu g / m l)\end{array}$ & $\begin{array}{l}\text { Time } \\
(\text { min })\end{array}$ & $\begin{array}{l}\text { Byssinotic } \\
\text { group }\end{array}$ & $\begin{array}{l}\text { Non-byssinotic } \\
\text { group }\end{array}$ \\
\hline 100 & 2 & $0 / 4$ & $0 / 11$ \\
\hline 500 & 2 & $1 / 4$ & $0 / 6$ \\
\hline 500 & 10 & $2 / 5$ & - \\
\hline 500 & 15 & $10 / 16$ & $0 / 12$ \\
\hline
\end{tabular}

${ }^{1}$ The occurrence of byssinotic symptoms 3 to 6 hours after challenge.

Questioning the byssinotic volunteers later in the week revealed that symptoms of byssinosis on Tuesday exposure to the cardroom environment either had not occurred or had been very much milder than usual. That is, the exposure to antigen in the laboratory had very closely imitated exposure to a cardroom environment both by provoking byssinotic symptoms and also in rendering the volunteers relatively insusceptible to exposure on Tuesday.

Attempts to increase the dose to produce $100 \%$ positive responses in byssinotics were not pursued because at concentrations of antigen higher than $500 \mu \mathrm{g} / \mathrm{ml}$ the Wright nebulizer tended to block and individuals objected to exposure for periods longer than 15 minutes.

\section{'Double-blind' trial}

Because of the entirely subjective nature of byssinosis it was considered to be essential to carry out a double-blind trial to obviate subject and observer bias.

\section{Subjects}

Three groups of subjects were used: 6 typical byssinotic cardroom workers with Schilling grades I or II byssinosis; 9 cardroom workers who had no symptoms of byssinosis but who had worked for at least 10 years in the cardroom; and 11 university staff.

\section{Method of challenge}

Because a saline solution of antigen was of a pale straw colour, both the test antigen $(500 \mu \mathrm{g} / \mathrm{ml}$ in isotonic saline) and the control solution (isotonic saline) were made up in opaque bottles. The subjects were all challenged on two occasions, once with antigen and once with control, but the order in which this was done was randomized and the identity of the contents of the bottle used was not known to the subject or to the individual carrying out the challenge.

The method of challenge was as previously described, the period of inhalation being 15 minutes. Challenges were made on two consecutive Monday mornings. Respiratory function tests.were carried out before and at intervals after challenge, as previously described. The subjects were asked to describe any symptoms which had occurred.

\section{Results}

After the experiment was completed the 'code' was broken and the results were analysed. These are presented in Table 10. Thus five of six byssinotics challenged by inhalation of cotton plant antigen developed symptoms of byssinosis whereas none of the same six had symptoms after control inhalation. Neither 'normal' nor non-byssinotic cardroom workers developed symptoms with either antigen or control inhalations.

Only one individual showed changes in $\mathrm{FEV}_{\mathbf{1} \cdot 0}$ and FVC determinations after challenge. This was one of the byssinotic group given antigen whose $\mathrm{FEV}_{1.0}$ and FVC fell significantly. It is of interest that this particular challenge was given on the Monday following a two-week period away from the cardroom.

TABLE 10

Results of Double-blind Inhalation Trial

\begin{tabular}{|c|c|c|}
\hline \multirow{2}{*}{ Group } & \multicolumn{2}{|c|}{$\begin{array}{c}\text { Positive responses after } \\
\text { inhalation of }\end{array}$} \\
\hline & Antigen & Saline \\
\hline $\begin{array}{l}\text { Byssinotic cardroom workers } \\
\text { Non-byssinotic cardroom }\end{array}$ & $5 / 6$ & $0 / 6$ \\
\hline 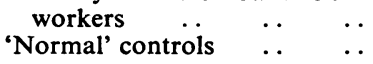 & $\begin{array}{l}0 / 9 \\
0 / 11\end{array}$ & $\begin{array}{l}0 / 9 \\
0 / 11\end{array}$ \\
\hline
\end{tabular}

\section{Discussion and conclusions}

A pure antigen has been extracted from cotton plant 
debris and from cardroom dust which is capable of inducing byssinotic symptoms when inhaled only by those individuals suffering from the disease. Normal individuals and cardroom workers who do not suffer from byssinosis fail to develop either symptoms or changes in simple respiratory function tests on the inhalation of similar amounts of the substance. Antibody directed against this antigen or possibly a nonantibody protein capable of reaction with the condensed tannin is present in the serum of all individuals but is at much higher titre in cardroom operatives. In the population at risk in the cardroom the titres against this antigen increase much more rapidly with length of service and continue to rise in those who develop symptoms of byssinosis. Those cardroom workers who do not suffer from the disease in spite of long exposure appear to 'level off' at a much lower titre. Thus a biological difference in behaviour has been demonstrated between these two groups of workers. It is tempting to relate this difference in behaviour to the development of the disease but sufficient evidence is not yet available to do so.

It was suggested by Massoud and Taylor (1964) that antigen-antibody complex formed during the inhalation of cotton plant dust was responsible for the pathology and pathophysiology of byssinosis. The type of reaction involved (type III, Gell and Coombs, 1968) occurs in such diseases as farmer's lung (Pepys, Riddell, Citron, and Clayton, 1962; Bishop, Melnick, and Raine, 1963), bird fancier's lung (Hargreave, Pepys, Longbottom, and Wraith, 1966), and many others, and is involved in varying degrees in the group of disease processes collectively known as pulmonary aspergillosis (Pepys et al., 1959). In these diseases the mechanism believed to be operating is the combination of antigen with precipitating antibody and the incorporation of complement into the complex. Certain complement fragments produced by this reaction have histamineliberating properties and polymorphonuclear leucocyte chemotactic properties (Müller-Eberhard, 1968). The liberation of lysosomal enzymes from the attracted polymorphs is the major factor in producing tissue damage. Complement binding is therefore a key point in the sequence of events. Irrespective of whether the combination of the cotton plant condensed tannin and serum is immunological in nature or not, it has been shown that when the reaction takes place at the surface of a red cell complement is bound. It is, therefore, theoretically possible for a type III reaction to take place following the inhalation of the cotton plant antigen in either case.

The classification of byssinosis as a disease of type III, however, presents difficulties. Although the timing of the symptoms following inhalation is in keeping with a type III reaction byssinosis is very different in many respects from other diseases in which this mechanism operates. Radiological changes are usual in type III pulmonary reactions in which fine miliary opacities are common (Pepys, 1969); radiological examination of cardroom workers does not show such changes. Histologically, the pulmonary diseases in which type III mechanisms operate show considerable tissue destruction with granulomatous inflammation. Although the information on the histology of byssinosis is scanty there is no evidence of such damage. In farmer's lung, withdrawal from exposure to the antigen is necessary for recovery otherwise progressive lung damage occurs; this is not the case in byssinosis, where, if exposure is continued daily over a long period of time, the symptoms of byssinosis cease after the first few days (Khogali, 1969). Despite these differences an atypical type III mechanism in byssinosis cannot be ruled out.

An alternative explanation of the observations is that the higher titres detected in byssinotic subjects could be the result rather than the cause of the disease. Some different method of 'handling' inhaled antigen might both induce the symptoms and also give rise to higher titres. In this respect studies of the interaction of antigen and pulmonary macrophages from byssinotic and non-byssinotic subjects might prove a profitable approach. Clearly, further work is required, particularly concerning the pathophysiology of this interesting disease.

We should like to thank the management and workers of the cotton mills concerned for their invaluable cooperation in this project and, in addition, those members of staff of the University and the Manchester Royal Infirmary who not only acted as a control group but also assisted in the collection of blood samples. This project was supported by a grant from the Medical Research Council.

\section{References}

Bishop, J. M., Melnick, S. C., and Raine, J. (1963). Farmer's lung: studies of pulmonary function and aetiology. Quart. J. Med., 32, 257-278.

Gell, P. G. H., and Coombs, R. R. A. (1968). Clinical Aspects of Immunology, 2nd ed. Blackwell, Oxford.

Hargreave, F. E., Pepys, J., Longbottom, J. L., and Wraith, D. G. (1966). Bird breeder's (fancier's) lung. Lancet, 1, 445-449.

Khogali, M. (1969). Investigacion de la bisinosis entre trabajadores de plantas desmotadoras de algodon en el Sudan. Med. de Empresa, 5, 128.

Massoud, A., and Taylor, G. (1964). Byssinosis: antibody to cotton antigens in normal subjects and in cotton cardroom workers. Lancet, 2, 607-610.

Müller-Eberhard, H. J. (1968). Chemistry and reaction mechanisms of complement. Adv. Immunol., 8, 1-80.

Pepys, J. (1969). Hypersensitivity Diseases of the Lungs due to Fungi and Organic Dusts. Karger, Basel.

, Riddell, R. W., Citron, K. M., and Clayton, Y. M. (1962). Precipitins against extracts of hay and moulds in the serum of patients with farmer's lung, aspergillosis, asthma and sarcoidosis. Thorax, 17, 366-374. 
Pepys, J., Riddell, R. W., Citron, K. M., Clayton, Y. M., and Short, E. I. (1959). Clinical and immunologic significance of Aspergillus fumigatus in the sputum. Amer. rev. Resp. Dis., 80, 167-180.
Schilling, R. S. F., Hughes, J. P. W., Dingwall-Fordyce, I., and Gilson, J. C. (1955). An epidemiological study of byssinosis among Lancashire cotton workers. Brit. $J$. industr. Med., 12, 217-227.

Received for publication June 11, 1970. 